to dine at the University Arms and, while they are in the taxi, Carefulcuss takes a bank-note from his pocket-book and hands it to Slippery, who puts it into the letter he has written to Bloodsucker and posts the letter in the hotel. The next day, when Slippery and his friend Archie Cadger are lunching the Hawks' Club, Bloodsucker comes up and places a $£ 50$ note upon the table and says: "See what you sent me by mistake." Slippery replies: "Thank God for an honest man. Let me have the change." Bloodsucker gives Slippery change. Slippery does not inform Carefulcuss of the mistake but buys with the money a motor-cycle from his friend Reginald Sellall. Carefulcuss, discovering the mistake about ten days later, reports the matter to the police. Slippery is committed for trial at the Assizes and is indicted for larceny.

Mr. G. J. Paull (Hardwick Society) and Mr. W. Hereward (Hardwick Society) conducted the prosecution, and R. Branston (Christ's) and E. C. S. Wade (Caius) appeared for the defence.

The jury acquitted the prisoner.

On March 10 Professor J.- H. Beale, Royall Professor of Law at Harvard University, gave an address to the Society on "The Westward Migration of Law in America."

T. S. P

\title{
CRANWORTH LAW SOCIETY OF DOWNING COLLEGE.
}

\section{Founded January, 1921.}

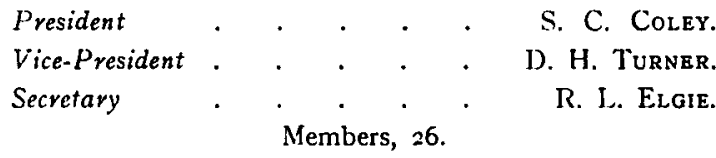

Ar the first meeting, on January 26, Professor Hazeltine welcomed the members of the Society at his residence, West Lodge. Mr. A. J. Berry then read a paper on "Some Scottish Judges of the Eighteenth Century."

At the second meeting, on February 4, the Secretary read a paper on "Lord Cranworth, Fellow of Downing and twice Lord Chancellor." In the words of The Spectator, Lord Cranworth "reached the" pinnacle of the Woolsack without arousing opposition, without excitement, and without eclat." Professor Kenny also spoke of Lord Cranworth as an undergraduate of Trinity and of his life at the Bar.

On March 3 a joint debate was held with the Jesus College Law Society on the motion: "That irresistible impulse should be recognized as a defence in English law."

P. F. Randall (Jesus) proposed and appealed for a wider construction of the answers given in M'Naughten's Case. Irresistible impulse was recognized in America and on the Continent. To punish a man labouring under it was "gratuitous cruelty."

E. E. Edwards (Downing) opposed: "The law must be both certain and reasonable. Can medical evidence be regarded as sufficiently convincing on this question? Irresistible impulse would be too ready a defence for any 
criminal; the law must presume a man sane until the contrary is clearly proved."

K. Gauba (Downing), speaking third, argued that English law was divorced from the researches of psychology and science. It did not administer justice.

C. Challen (Jesus), speaking fourth, predicted that our moral stability would be weakened if such a defence were allowed by the criminal law.

J. D. Fell, R. E. Seaton, and C. F. H. Hamilton also spoke. The motion was defeated by seven votes to ten.

Professor Hazeltine will address the Society at the beginning of the Easter Term, and after the tripos it is proposed to hold a Society dinner.

R. L. E.

\section{EMMANUEL COLLEGE LAW SOCIETY.}

Founded October, 1906.

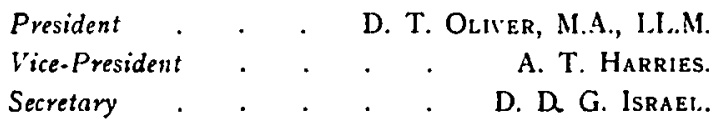

Members, 17.

ON November 11 a debate was held, the motion being: "That a country deserves as many criminals as it has."

W. H. Cocker, L. L. Irwin, and A. T. Harries spoke for the motion; T. Swan, J. Mostyn, and D. D. G. Israel against.

On November 25 the President presided over a case on nuisance and trespass by aeroplanes, the facts of which are given in the Trinity College report.

Counsel.-For appellant, A. T. Harries and R. T. C. Jones; for respondent, D. D. G. Israel and E. V. White.

Judgment for respondent on both counts.

On February 14 the Society entertained the Caius College Law Society, when a House of Lords appeal case was heard.

On the Bench.-Dr. Winfield, Mr. Oliver, and Mr. McNair.

Counsel.-For appellants, T. Swan and W. H. Cocker; for respondents, T. Reay and N. Thayer.

The facts were as follows:-

A Colonel Bloodyer had unsuccessfully sued the respondent, General Firebrace, for maliciously and wrongfully causing his retirement from the Army, the General having, through dislike of the Colonel, suppressed one of his reports and himself sent in an adverse report on the Colonel's conduct of certain operations in the field. The Court unanimously reversed the decision of the Court of Appeal and gave judgment for Colonel Bloodyer.

On March 2 Mr. A. D. McNair (Caius) read a paper on "Shakespeare and Magna Carta," pointing out the reasons for the omission of any reference to Magna Carta in Shakespeare's King John.

D. D. G. I. 